\title{
Global Minds, Local Bodies: Kosovar Transnational Connections Beyond British Columbia
}

\author{
Kathy Sherrell and Jennifer Hyndman
}

\begin{abstract}
In 1999, 905 Kosovar refugees settled in the province of British Columbia (BC) in Canada. Despite their sudden and forced departure, many have maintained contact with and returned to visit Kosovo/a. We contend that these transnational links are different for refugees than for other classes of immigrants. In this case, "refugee transnationalism" refers to the social, cultural, economic, and political relations that Kosovar refugees in Canada keep with those in Serbia and Montenegro (formerly the Federal Republic of Yugoslavia). A salient feature that shapes Kosovar transnationalism is the uncertain status of the region of origin, namely Kosovo/a. Based on interviews and focus groups with Kosovars in seven BC cities, we discuss the quality and distinctiveness of transnational links among this refugee group and their implications for settlement and integration in Canada.
\end{abstract}

\section{Résumé}

En 1999, 905 réfugiés kosovars se sont établis dans la province de la Colombie-Britannique (C.-B.) au Canada. En dépit de leur départ rapide et forcé, nombre d'entre eux ont gardé contact avec le Kosovo/Kosova et y ont séjourné. Les auteures soutiennent que ces liens transnationaux different selon qu'il s'agit de réfugiés ou d'autres catégories d'immigrants. L'expression " transnationalisme des réfugiés " réfêre ici aux relations sociales, culturelles, économiques et politiques que les réfugiés kosovars au Canada conservent avec les réfugiés de Serbie et du Monténégro (anciennement la République fédérale de Yougoslavie). Le statut incertain de la région d'origine est l'un des traits saillants à la base du transnationalisme kosovar, soit le Kosovo/Kosova. À partir d'interviews et de discussions menées avec des Kosovars dans sept villes de la C.-B., les auteures étudient les spécificités et le caractère distinct des liens transnationaux au sein de ce groupe de réfugiés et les implications pour leur établissement et leur intégration au Canada.

$\mathrm{R}$ esettlement to another country is often considered a "durable solution" to displacement and the endpoint of the refugee experience. A refugee's attachment to her region of origin does not simply end, however, once she arrives in a host society such as Canada. Achieving full participation in Canadian society is a long-term process influenced by events and expectations in the country of origin as well as the host country. "Immigrants take actions, make decisions, and develop subjectivities and identities embedded in networks of relationships that connect them simultaneously to two or more nation-states." ${ }^{1}$ Transnationalism recognizes that settlement and "integration" occur within the context of two or more locations, and that (new) identities are forged across this space. As such, settlement and integration cannot be fully understood without consideration of the ongoing social, political, and economic ties that are developed and maintained across the borders of the two states. Incorporating a transnational analysis recognizes that refugees retain and develop multiple relationships both within and between the sending and receiving countries. Processes of immigrant integration and emerging social cohesion in Canadian society may vary from large to small urban centres, across immigrant classes, and within specific immigrant groups. ${ }^{2}$ 
This paper examines the quality and distinctiveness of transnational links among Kosovars, a group that came to Canada as refugees in 1999. We contend that transnationalism is different for refugees than for other classes of immigrants, and note that the uncertain status of the Kosovars' region of origin, namely Kosovo/a, shapes transnational relations as well as settlement and integration in the province of British Columbia in Canada (BC). ${ }^{3}$ Far from abandoning all ties with Kosovo/a, the Kosovars interviewed have established a multitude of relationships and identities that extend beyond Canadian borders. Our findings suggest that the transnational linkages Kosovars in BC maintain with Kosovo/a do not necessarily detract from their "integration" in Canada. Continued uncertainty in Kosovo/a may in fact hasten settlement in Canada.

\section{Living Lives across Time and Space}

"The word 'immigrant' evokes images of permanent rupture, of the abandonment of old patterns of life and the painful learning of a new culture and often a new language." 4 Although this conception envisions migrants as moving permanently from one bounded nation to another, others favour an "approach to migration that accents the attachments migrants maintain to families, communities, traditions and causes outside the boundaries of the nation-state to which they have moved." 5 Since the late 1980s, researchers have theorized the ethnic and cultural identities and networks of economic, political, and cultural relations that cross national borders and boundaries. Proponents of transnationalism argue that settlement occurs within a context that simultaneously connects immigrants and refugees to multiple nation-states. ${ }^{6}$ Advances in transportation and communications technologies, and their increased accessibility, facilitate migration and improved communications. Migrants develop relations and identities that are no longer anchored in one country, but rather span both their country of origin and country of resettlement. ${ }^{7}$

Basch, Glick Schiller, and Szanton Blanc define transnationalism as "the processes by which immigrants forge and sustain multi-stranded social relations that link together their societies of origin and settlement." this definition by arguing that transnational relations must be recurring activities that cross national borders and involve a significant number of people. ${ }^{9}$ This scale and intensity of relations, Portes asserts, differentiates transnational activities from those of earlier migrants. ${ }^{10}$ Critics of Portes, including Al-Ali and Koser, contend that his insistence on "a significant number of people engaged in sustained relations over time" as a prerequisite to transnational migration is too rigid. ${ }^{11}$
Transnational approaches to migration research must fully consider the ways in which refugee transnationalism may differ from that of immigrant transnationalism. ${ }^{12}$ Forced migration is distinct from voluntary migration in the development of transnational relations.

[The] immediate concern of recent arrivals has been to try to secure their positions in their new host countries. Few have yet had time even to re-establish contacts with relatives and friends left behind ... far less become involved in transnational activities, even those as basic as sending remittances. ${ }^{13}$

Al-Ali et al. distinguish "transnational activities," which may include political, economic, social, and cultural activities at multiple scales from the individual to the institutional, from "transnational capabilities," which recognize that the ability to engage in transnational activities is dependent upon the resources available to migrants. ${ }^{14}$ The ability to engage in transnational activities in the "home" country may be negatively affected by unemployment, financial instability, and language barriers in the receiving country. This distinction is a useful extension to ideas forwarded by Portes and Portes et al., as it begins to take into consideration the actual ability of people to engage in transnational activities. ${ }^{15}$ Portes' research has historically focused on economic, voluntary migrants sending significant remittances.

Recently arrived refugees and immigrants, however, may not be in a position to engage in transnational activities. Sporadic remittances of money or gifts may represent the beginnings of transnational activities and relations for recent refugees who are struggling to establish themselves in the host society. The emergence of transnational activities will be affected by conditions within both the host and the sending country, and can vary over time and space depending on the attitudes of home states, differences in current status, and differences in conditions in home society. ${ }^{16}$

Although much of the transnational literature focuses on economic activities, such as remittances, and political activities, a few researchers have foregrounded social relations. ${ }^{17}$ Mountz and Wright, for example, explore the ways in which transnational migration between San Augustan, Oaxaca, and Poughkeepsie, New York, have altered the social practices of Mexican migrants in Poughkeepsie and their families in San Augustan. ${ }^{18}$ These authors show how transnational migration transforms social practices both in the sending and receiving countries. Although it is difficult to examine social relations without considering economic and political linkages, the least attention has been paid to the establishment and implications of transnational social practices. 


\section{Research Approach}

Our research draws upon forty individual interviews and seven focus groups with Kosovar refugees, sponsors, and key informants that were conducted between May 2002 and March 2003, in seven BC communities: Chilliwack, Abbotsford, Kelowna, Vernon, Vancouver, Surrey, and Burnaby. Approximately equal numbers of Kosovar men and women, aged twenty-one to seventy-eight, participated in this research. Because the English language ability of the Kosovar participants varied from those who claimed fluency in English to those with little ability to speak English, interpreters were provided during focus groups and individual interviews. Using interpreters ensured people could respond in the language with which they felt the most comfortable. Although not generalizable, these findings expose the character and intensity of transnational processes among one refugee group and have implications for settlement and integration.

The analysis of transnational relations and activities was included as one part of a study examining the settlement of Kosovar refugees who arrived in British Columbia during the summer of $1999 .{ }^{19}$ Questions about transnational linkages were integrated into the research design to ascertain how, if at all, the development of multiple and complex linkages, be they economic, social, or political, affects the settlement experiences of Kosovar refugees in British Columbia.

Heeding the criticisms of earlier studies of transnationalism, we posed questions related to transnational linkages to all participants in our study. Portes, Guarnizo, and Landolt, and Portes, warn that transnational linkages are overdrawn by sampling only on the dependent variable, i.e. those who participate in transnational exchange. ${ }^{20}$ Hiebert and Ley also caution against this methodological pitfall. ${ }^{21}$ In their statistically significant survey of Vancouver immigrants, they add an important dimension to research on transnationalism: quantitative methods with arguably more generalizable results. Including questions about transnationalism on an interview schedule concerned primarily with settlement in smaller cities allowed us to ascertain whether transnationalism was relevant to the experiences of the refugees contacted. In other words, our sample is not skewed in favour of those for whom transnationalism is already important.

\section{Distinguishing "Refugee Transnationalism"}

Portes characterizes transnationalism as the formation of

dense networks across political borders created by immigrants in their quest for economic advancement and social recognition. Through these networks, an increasing number of people are able to live dual lives. Participants are often bilingual, move easily between different cultures, frequently maintain homes in two centres, and pursue economic, political and cultural interests that require their presence in both. ${ }^{22}$

In the Canadian context, Hiebert and Ley found higher incidences of transnationalism among economic and family-class immigrants than among refugees. ${ }^{23}$ Unlike migrants, who have prepared themselves to begin their lives in a new country, refugees have been forced to flee their homes and their country. ${ }^{24}$ As such, they may lack the financial resources and social networks that would hasten their integration. The majority of Kosovars interviewed, for example, would not meet the conditions outlined by Portes: few spoke English upon arrival in Canada, and most Kosovars interviewed continue to find it difficult to move between countries for both economic and political reasons. Unemployment and underemployment, the high cost of travel to Kosovo/a, and lack of travel documents curtail the potential for people to travel directly to Kosovo/a or to make frequent returns. ${ }^{25}$ Unlike the experiences of Bosnian and Eritrean refugees in the UK and the Netherlands, however, the Kosovars could not rely on pre-existing networks established by earlier labour migrants as there were few Kosovars living in BC prior to $1999 .{ }^{26}$ Limited financial resources and political instability impair the ability of Kosovars to move freely between their country of origin and the host country. Their situation raises the question of whether "migrant transnationalism" should be differentiated from that of "refugee transnationalism."

Most immigrants and refugees who successfully apply to come to Canada have upwards of a year to prepare for their journey. Given efforts to ethnically cleanse Kosovo/a by the Milosevic regime, the Kosovars had little time to prepare for their departure. ${ }^{27}$ Research undertaken in Alberta found that the average time between when Kosovars left their homes in Kosovo/a and their arrival in Canada was fiftytwo days, compared to five years for non-Kosovar participants in the study. ${ }^{28}$ "Refugee transnationalism" differs markedly from that of other immigrant classes because refugees are forced to leave their homes, often with little notice.

In employing the term "refugee transnationalism" we recognize that competing discourses are embedded within the concept. "Refugee" is a political and legal category framed by "international" discourse focused on the relation of nation-states to one another. Refugees are outside the borders of their country, and are unable or unwilling to avail themselves of protection from their government. The idea of "refugee transnationalism," however, reframes the category "refugee" as simultaneously embedded within 
both the country of origin and the host society to consider the ways in which refugees develop identities and form ongoing relationships. In this way the state is decentred as the only scale of analysis, but remains an important consideration in determining prospects for return.

Refugees have different motivations and resources available to them than do other migrants who may form transnational networks in a "quest for economic advancement and social recognition." 29 As such their relationships differ significantly from those of migrants who are socially and financially prepared to leave. Unlike many asylum seekers whose immediate concerns are to establish themselves in their host country, the Kosovars benefited from being granted immediate recognition as refugees and their legal status as landed immigrants. ${ }^{30}$ In this respect, the experiences of Kosovars differed from those of the Bosnians and Eritreans in England who expressed "concern and insecurity with respect to their legal status." 31 In contrast, the Kosovars' position in Canada is more certain than that in Kosovo/a. The war in Kosovo/a has not ended in the formation of an independent state, as it did for Bosnians and Eritreans, but rather in a "proto-independence" as a temporary UN protectorate. ${ }^{32}$

The UN Security Council Resolution 1244 of June 10, 1999 , led to the establishment of the UN mission in Kosovo, UNMIK; the resolution established a transitional administration but with no clear end status for Kosovo. ${ }^{33}$ The preamble of the resolution reaffirms the sovereignty and territorial integrity of the Federal Republic of Yugoslavia over Kosovo; it calls for "self-administration" and "substantial autonomy," but not a separate state. This stands in clear contrast, for example, with Security Council Resolution 1272 for East Timor, which clearly stated that the aim of the UN transitional administration was to be a transition to an independent East Timor. ${ }^{34}$ The effect of this resolution, in conjunction with political developments in Serbia and Montenegro (especially the removal of Slobodan Milosevic as President), has served to heighten political uncertainty.

The character of this UN resolution has shaped Kosovo/a's indeterminate political status. That is, Kosovar identification with Canada is not solely a product of the indigenous politics of Serbia and Montenegro. UN mandates and multilateral interventions into Kosovo have also played a part in shaping these transnational relationships, albeit indirectly. In a sense, multilateral political relations among states and areas affected by conflict and ethnic cleansing shape transnational identity formation among displaced Kosovars now living in BC. The continued presence of the international peacekeeping Kosovo Force (KFOR) and the uncertain political fate of Kosovo/a (i.e. as a province of Serbia or an independent state) prolong this uncertainty and hasten settlement in Canada. "Home" is marked with uncertainty about the political future.

Rebuilding Kosovo/a requires considerable investment, but several respondents felt it was impossible until there was political stability in the region and clarity on its status. For one person, questions of citizenship are complicated by political uncertainty in Kosovo/a.

There is a real need in Kosovo for people who can help rebuild the economy, but the political status of Kosovo has not changed yet. So, you can't really rebuild an economy without an adequate solution to the political issues because you don't have the security for investment. Just recently there were elections for the parliament... They say the president of Kosovo, but the president of what? President of the municipality or ... what is it? So without that the economy will never move forward. ${ }^{35}$

For the past four years, "Kosovo has existed in a constitutional limbo... At issue is whether the province will become independent or remain part of Serbia. The Kosovo Albanians want independence; the Serbs oppose it." ${ }^{36}$ Initial talks between Kosovo's ethnic Albanian government and Serbled government were held on October 14, 2003, in Vienna. ${ }^{37}$ The continued political uncertainty has had economic consequences:

Nobody will put money in because they have no guarantee that the incoming government will not confiscate their investment. This has condemned the province to a commercial life that today consists of smuggling, subsistence farming and high unemployment. $^{38}$

In July 2003, for example, the unemployment rate in Kosovo/a was estimated at 57 per cent. ${ }^{39}$ For one person who is going to school to upgrade previous qualifications, the job opportunities in Kosovo/a are scarce:

There is not too many opportunities over there because the war happened and everything is destroyed and lots of houses were burnt and factories. We don't have one factory over there that is working right now.

Ongoing political uncertainty in Kosovo/a precludes the likelihood of a rapid solution to its economic crisis. "Factories lie dormant with little hope of investment. The UN says it must tackle standards before it can tackle Kosovo's final status. But without status, no-one knows what they are investing their money in." ${ }^{40}$ Reflecting on a return visit to Kosovo/a, one informant noted "it was good to see family again, but the country was devastated.” Talk about return 
is mitigated by the current devastation in Kosovo/a. Widespread unemployment and the absence of health care facilities make return much less desirable. The majority of Kosovars interviewed do not foresee a future there, at least in the immediate few years. One respondent noted:

I am used to living with problems for last ten years, but I have chance when Kosova get freedom I am sure I will find job then. Company called many times because you need to come we don't have like you, but I think when I came to Canada I would try to stay in Canada. I have no house now [in Kosovo/a]. I have nothing, and I know Kosova remain in bad situation for a long time.

Although this person is not ruling out an eventual return to Kosovo/a, the current conditions prohibit immediate return. Life in Canada, despite unemployment for many, offers more possibilities than in Kosovo/a. ${ }^{41}$

\section{Place and the Importance of Networks}

Three years after their arrival in Canada, all of the Kosovars interviewed maintain ongoing contact with family and friends in Kosovo/a on a weekly, and in many cases a daily, basis. Communication is mainly by phone and mail, although electronic means of exchange, such as e-mail and Internet messaging services, have been important for Kosovars in major urban centres, particularly Vancouver. Similarly, Bosnian and Eritrean refugees in the UK, Germany, and the Netherlands engage in regular contact with family in their respective home countries, primarily by phone, although a small number of Bosnians reported using the Internet. ${ }^{42}$ In addition to phone calls and letters, the Internet has been an important news source that has enabled Kosovars to stay abreast of daily events in Kosovo/a. Kosovars interviewed in Vancouver, in particular, regularly use computers (as do others in Kelowna, Chilliwack, Abbotsford, and Surrey as well). One Kosovar stated,

Through Internet is everything available. You can search anything you want-radio, TV, theatres, political situation, economy, everything. Also there is phone calls, through talking to people and messenger. They will tell us what's new, what's good, what's bad.

Weekly Internet newspapers and on-line news agencies that are published in Albanian have allowed the Kosovars to monitor current events. In Vernon, where the Kosovars we interviewed were not computer literate, the employment counsellor at the local immigrant and refugee-serving agency would print out the weekly on-line newspaper for them. The Albanian-speaking Kosovar diaspora spans the globe, the dispersion being primarily a result of the 1999 exodus. When asked if he kept in contact with people in Kosovo/a, one Kosovar in Vancouver stated:

Every day and every night. Homesick all the time ... Usually first we start with phones, but usually now with the Internet. Every day. Like we have ... [a] specified time where we meet each other. We waiting each other to contact ... It's amazing some of the things that keep me here because I can feel it. I'm many times, I play some music and Albanian music, with all kind of actors and singers and stuff. That's keeping me really ... healthful. It keeps me all the time in life. Like ... I can make utmost for life. I am home.

"Home" then is not bounded by the borders of one province or country but simultaneously exists across the borders of both Kosovo/a and Canada. Even as they struggle to build new lives in Canada, many Kosovars maintain ongoing linkages with Kosovo/a. Over time, however, some Kosovars indicated they have begun to look at the news less frequently than they did three years earlier when they first arrived.

[I] used to [keep up with the news], but not anymore . . . [Unless] someone mentions something . . . I don't usually search for news.

Similarly, Hiebert and Ley found the length of settlement is important in the maintenance of transnational relations and activities, with recent immigrants more likely to maintain contact with friends and family in the country of origin. ${ }^{43}$ Settlement requires establishing new livelihoods in a new location and often in a different language.

Migration and settlement force people to negotiate new identities which are not bounded by the borders of a single nation-state. How are these evolving transnational identities important in relation to participation in Canadian society? Like the Bosnians studied by Al-Ali et al., "being Kosovar" "governs many people's sense of identity and sense of belonging." 44 In spite of their commitment to obtaining Canadian citizenship, respondents confirmed having multiple identities.

In Canada I identify myself as an Albanian ... but I ... stopped in Austria on the way... [to visit] Kosova, and I leaned more towards identifying myself as a Canadian there ... I'm not sure [why], maybe just the politics that's been going on there ... [interviewer - maybe it felt safer] ... safe ... not much safer, but I don't know, sometimes we're embarrassed too. Because not everyone understands. You know, they judge you by that thing.

Identity is relational, especially with regard to place. One woman who originally settled in the United States suggested: 
Actually I feel more American than Albanian [be]cause I miss more New York than my country ... My family is there and I [have] lots of friends in New York ... and I haven't been to Kosova in three years ... Where the family is, the heart is.

One Kosovar suggested the passing of time in Canada could change his/her identity.

I have ... a lot of contact with people [from Kosovo/a that have been] here fifteen years ... [When] I say I am from Kosovo, they say, I was saying that but now I saying now Vancouver is my home, or Canada is my home ... Probably what is true if I am staying here fifteen years, twenty years then it's different, then lose all contacts with my people back home and probably then, after ten, fifteen years I belong, I am from here, but it's difficult to adjust right now.

For another person, Canadian citizenship is imagined as being a new aspect of their identity as Kosovar.

[I am a] Kosovar but [ $\mathrm{I}$ am a] landed immigrant in Canada. That is that. But when I think of myself I am Kosovar. And I'm going to be ... [ [as long as] I'm alive. Even if I get Canadian citizenship ... I am citizen of Canada ... and I really appreciate that. But I'm still Albanian ... , Kosovar from Kosova.

Integration into Canadian society, then, is imagined as "becoming Canadian” while still maintaining Kosovar identity and culture. ${ }^{45}$ Becoming Canadian, then, represents a facet of a continuously emerging identity. Another person talked about increasingly feeling like he had a home in both Kosovo/a and Canada.

If I was born here, maybe [it] would be different . . . but I was born over there ... So it's hard for me to say ... I'm Canadian yet. But I feel like ... I have home here too ... When I went [to Kosovo/a] for two months last year. It was kind of pushing me sometimes to go back there. Pulling me to come over here... I see myself like fifty-fifty.

The establishment and maintenance of transnational social relations reconceptualizes notions of "home" (as stretching across space) and encourages the renegotiation of identity, both an individual and a culturally distinct group that shares a language.

In order to avoid the necessity of starting over, one family has elected to take advantage of a provision within Canada's Resettlement Assistance Program (RAP) that enables students to travel back to the country of origin. This enables the couple to travel "back and forth to school without stopping their landing in Canada." As such, this family lives in Kosovo/a during the school year and then in Canada during summer breaks. Despite feelings of indifference towards Kosovo/a, dividing time between the two countries has distinct personal advantages for this family: continued progress towards professional accreditation in Kosovo/a (after which the person intends to write qualifying exams in Canada), and continued progress towards obtaining Canadian citizenship. The degree to which Kosovars have developed transnational social relations and identities varies significantly, however, within the population interviewed. Evidence does point to the existence of tight transnational social networks among the Kosovars interviewed. Interest in news "back home" has waned for some and may well decline further over time. ${ }^{46}$ Although only one person talked about being in contact with Kosovars in other Canadian cities, there appears to be a rich network of information concerning living and employment conditions in these cities.

\section{Transnational Capacities}

As they negotiate settlement in Canada, many of the Kosovars interviewed expressed the desire to help family members still living in Kosovo/a by sending money. Unemployment and underemployment, as well as the high costs of living in BC, however, have prevented many of the Kosovars from sending regular remittances. These findings differ significantly from those of Al-Ali et al. who reported that the majority of Bosnians and Eritreans they interviewed were sending regular remittances to family and friends in Bosnia and Eritrea. ${ }^{47}$ The perceived obligation to send money to help with daily living expenses in Kosovo/a has required some Kosovars to make personal sacrifices here in Canada.

[W] have like obligation to help them. Doesn't matter if I am suffering here, we have that respect and need to help them ... My family ... is suffering. We need to ... help them. We have that responsibility. [It] doesn't matter how. You working hard here or you don't have [money] to go to spend ... You need to have money [to send home].

Men, in particular, expressed a social obligation to help support parents in Kosovo/a.

Usually parents . . choose one of the children [and] he have responsibility to support them and to live with them to the end.

The sacrifices made to help those in Kosovo/a obviously shape the social activities Kosovars can participate in here in Canada. In their work with Bosnian refugees, Al-Ali et al. found " $[t]$ hose with additional income . . . are often faced with a choice between saving money to return, supporting 
their family in Bosnia, or starting to build a new life in the host country." 48 Nonetheless, family and friends are in their thoughts; the stress of trying to make ends meet in $\mathrm{BC}$ is compounded by the acute housing and income needs of those left behind.

Currently, only three families out of twenty-four send semi-regular remittances of $\$ 500$ to $\$ 1,000$ every three to six months to family and friends living in Kosovo/a. Many of the Kosovars interviewed indicated they send sporadic gifts of money or clothes because they are not in a position to send regular remittances. ${ }^{49}$

I send [gifts to] ... my brother and sister ... Sometimes I wish I could send more, but now [there is] . . not enough for me here.

The inability to send regular remittances to Kosovo/a increases the stress of settlement in Canada.

Like $\$ 20$ or $\$ 50$ dollars just to say hi, and that I don't forget you. It is not big money ... I have my uncle [and] my cousin ... their houses were burnt and for winter they don't have a house. They sleep in a tent and the winter it is minus 25 or minus 30 sometimes. These poor people have nothing. No roof, no house, no nothing: they sleep outside ... I cannot help them even if I want [to]. It is very hard and sad.

Remittances that are sent to friends and family living in Kosovo/a are delivered through informal networks as opposed to through formal transfer systems, such as Western Union. As people return for visits, others will send money or gifts for friends and family in Kosovo/a.

\section{Keeping Options Open}

Questions about the desire of Kosovars to obtain Canadian citizenship as they become eligible were posed. Although the Kosovars interviewed are at differing stages of their eligibility (some were not eligible to apply while others had already applied at the time of the interview), they were unanimous about their intention to have Canadian citizenship: it offers security and facilitates mobility. Speaking of a Canadian passport, one respondent noted:

[I] want it so I can visit Kosova, currently [I] can't without lots of visas, and [we are] prohibited from travel in Yugoslavia, [but I] want to travel to Kosova.

Upon receiving Canadian citizenship, one family repatriated to Kosovo/a to rebuild their lives. Canadian citizenship, in this example, acts as a form of insurance: if this family can not forge a livelihood upon their return to Kosovo/a, they may choose to return to Canada. ${ }^{50}$ Kosovars " $[\mathrm{k}]$ eep their options open" by maintaining access to multiple nationstates and thus increasing stability and security. ${ }^{51}$ This raises interesting questions about whether other people will return to Kosovo/a after obtaining their Canadian citizenship and, in turn, what kind of citizens they will become in relation to Canadian society. ${ }^{52}$ While beyond the scope of this paper, this issue has been widely addressed among economic immigrants to Canada, but not among refugees. ${ }^{53}$

Formal political involvement in Kosovo/a, through voting, is highly variable among the Kosovars interviewed. ${ }^{54}$ Although only five Kosovars out of thirty-four indicated that they had voted in the 2002 elections in Kosovo/a, over 50 per cent of the Kosovars interviewed say they intend to vote in future Kosovar elections. ${ }^{55}$ Approximately 30 per cent of the Kosovars interviewed, however, have no intention of voting in Kosovo/a in the future. Reflecting on his knowledge of local issues and candidates at home in Kosovo/a, one Kosovar reasoned, "I don't know most of the people who are running ... my vote would be [an] uneducated one." Geography also played a role in the decision whether or not to vote in Kosovar elections: "I'm here now and probably will not vote." One Kosovar related his parent's inability to vote in Kosovo/a as they lack updated documentation to prove they are citizens of Kosovo/a:

I can [vote] but my parents cannot ... because they didn't have updated information ... It is really very frustrating there trying to get all the information that you lived there but the thing is that you cannot because everything is destroyed.

Judah reports that as the Kosovars fled,

the police stripped most refugees of their documents ... [I]n this way Milosevic may have hoped to make it impossible for them to come home later as they would have no way of proving that they were Yugoslav, as opposed to Albanian or Macedonian citizens. ${ }^{56}$

These factors increase the difficulty of proving former $\mathrm{Yu}$ goslavian citizenship and problematize voting prospects. In contrast, all of those who apply for Canadian citizenship are likely to get it. While voting is not an arduous level of political participation, it does signal the Kosovars' priorities and intentions to vote in Canada. Connections to Canada already appear stronger on some counts.

\section{Conclusion: Constitutive Outsides}

Settlement and integration occur within the context of a nexus of social, political, and economic relations that simultaneously connect immigrants and refugees to multiple na- 
tion-states. Unlike many asylum seekers and refugees with temporary status, whose immediate energies are focused on obtaining status in the host country, the Kosovars in Canada benefited significantly from being granted immediate recognition, legal status, and basic support. For the Kosovars, their status in Canada is far more certain than it is in Serbia and Montenegro.

Continued political and economic uncertainty in Kosovo/a is due in part to the nature of the UN resolution which authorized multilateral intervention in Kosovo/a. Kosovo/a's future remains uncertain, and this appears to have the effect of hastening settlement in Canada for Kosovar refugees. The inability to foresee a future at "home" in Kosovo/a in the next five to ten years has meant that Kosovars in Canada plan to stay and have begun to establish a future for themselves. "Home" in Kosovo/a is marked with an uncertain economic and political future.

For some, Canadian citizenship offers security and a new beginning in a new country. For others it offers mobility and the opportunity to visit Kosovo/a without restrictions, but with an "insurance policy" of return to Canada. For most, Canada offers better economic and political prospects than Kosovo/a, at least in the medium term. The transnational ties, identities, and relationships forged between Kosovo/a and British Columbia shape the daily lives of the Kosovars in BC. The establishment and maintenance of transnational relations has resulted in a reconstitution of "home" for the Kosovars interviewed. "Home" is a social field that straddles the borders of both $\mathrm{BC}$ and Kosovo/a.

The transnational identities and relationships developed between Kosovo/a and Canada, and among members of the diaspora, are an expression of extant social networks with family and friends. While modest, these networks are also the spaces in which remittances and gifts circulate. In BC, ample evidence points to the existence of transnational information networks. Our methods allowed us to document transnational "traffic" but not to measure whether this "traffic" wanes over time as integration in Canada proceeds.

While we cannot definitively prove that transnationalism augments settlement and integration in the Canadian context, neither did we find evidence to suggest that it detracts from participation in BC and Canadian society. Indeed, the uncertain political status in Kosovo/a appears to act as a "constitutive outside," constituting Kosovars as Canadian to a greater extent because their status in Serbia and Montenegro is uncertain and unattractive. ${ }^{57}$ Nonetheless, attachments and belonging to more than one place makes "home" difficult to define. Even as he plans a future for his family in Canada, one Kosovar lamented:
I'm Albanian. Born Albanian, and Albanian I'll die. My heart is there ... I have no way of helping them in any way, but... that's my country and that's my homeland.

In the absence of political stability and economic security in Kosovo/a in the foreseeable future, a home in Canada offers more certainty and opportunities to the Kosovars.

\section{Notes}

1. L. Basch, N. Glick Schiller, and C. Szanton Blanc, Nations Unbound: Transnational Projects, Postcolonial Predicaments, and Deterritorialized Nation-States (New York: Gordon and Breach Publishers, 1994), 7.

2. Immigration classes refer to specific categories of immigrants landed in Canada; they include "economic," "family," and "refugee" See Citizenship and Immigration Canada (CIC), Canada's Immigration Law, 2002; < http://www.cic.gc.ca/english/pub/imm-law.html\#act2> (accessed February 17, 2004).

3. In Kosovo/a, "political identities and territorial claims are contested between two cultures with . . different languages;" see W.J. Buckley, ed., Kosovo: Contending Voices on Balkan Interventions (Grand Rapids: William B. Eerdmans, 2000), 469. Kosovars and Serbians have different names for some places and different spellings for others. These differences speak to different representations and understandings of these places. While this research focuses on Kosovars' settlement in Canada, these differing representations of place have implications for the research here. The names and spellings that are employed reinscribe particular histories, understandings, and ways of knowing, and ultimately affect the information that is obtained. "I thought you were saying 'Kosovo.' 'Kosovo' is more Serbian and 'Kosova' or 'Kosove' is okay" (Interview 103, Kosovar, Vancouver). Others, however, felt our use of "Kosova" was unnecessary as the province is internationally recognized as "Kosovo." During the interview process Kosovars were asked to use whichever name they preferred. In our writing we have elected to use "Kosovo/a," so as not to privilege either representation or way of knowing these places.

4. Basch et al., 3-4.

5. S. Vertovec, "Transnationalism and Identity," Journal of Ethnic and Migration Studies 27 (2001): 574.

6. N. Al-Ali and K. Koser, "Transnationalism, International Migration and Home," in New Approaches to Migration: Transnational Communities and the Transformation of Home, ed. N. Al-Ali and K. Koser (New York: Routledge, 2002), 1-14; G. Dona and J. W. Berry, "Refugee Acculturation and Re-acculturation," in Refugees: Perspectives on the Experience of Forced Migration, ed. A. Ager (New York: Pinter, 1999), 169-95; C. Dwyer, "Migrations and Diasporas," in Introducing Human Geographies, ed. P. Cloke, P. Crang, and M. Goodwin (New York: Arnold, 1999), 287-95; S. Vertovec, "Conceiving and Researching Transnationalism," Ethnic and Racial Studies 22 (1999), 447-62; A. Portes, "Immigration Theory for a New Century: Some Problems and Opportunities," International 
Migration Review 31 (1997): 799-825; M. Kearney, “The Local and the Global: The Anthropology of Globalization and Transnationalism," Annual Review of Anthropology 24 (1995): 547-65; R. Rouse, "Making Sense of Settlement: Class Transformation, Cultural Struggle and Transnationalism among Mexican Migrants to the United States?" Annals of the New York Academy of Science 645 (1992): 25-52; and Basch et al.

7. Vertovec, "Transnationalism and Identity."

8. Basch et al., 7

9. A. Portes, "Conclusion: Towards a New World-The Origins and Effects of Transnational Activities," Ethnic and Racial Studies 22(1999): 464-77; Portes, "Immigration Theory for a New Century."

10. A. Portes, L.E. Guarnizo, P. Landolt, "The Study of Transnationalism: Pitfalls and Promise or an Emergent Research Field," Ethnic and Racial Studies 22 (1999): 217-37; Portes, "Immigration Theory for a New Century."

11. Al-Ali and Koser, 2.

12. N. Al-Ali, R. Black, and K. Koser, "The Limits to 'Transnationalism': Bosnian and Eritrean Refugees in Europe as Emerging Transnational Communities," Ethnic and Racial Studies 24 (2001): 578-600; N. Al-Ali, R. Black, and K. Koser, "Refugees and Transnationalism: The Experience of Bosnians and Eritreans in Europe," Journal of Ethnic and Migration Studies 27 (2001): 615-34; K. Koser, "From Refugees to Transnational Communities?" (paper presented at the Conference on New Approaches to Migration: Transnational Communities and the Transformation of Home, University of Sussex, 21-22 September 1999); and Al-Ali and Koser.

13. Al-Ali et al., "The Limits to 'Transnationalism,"” 587.

14. Al-Ali et al., "The Limits to "Transnationalism."”

15. Portes, "Immigration Theory for a New Century"; Portes, "Conclusion: Towards a New World"; and Portes et al.

16. Al-Ali et al., "The Limits to 'Transnationalism."”

17. For a further discussion of remittances see: Portes, "Immigration Theory for a New Century"; Vertovec, "Transnationalism and Identity"; N. Van Hear, "Sustaining Societies under Strain: Remittances as a Form of Transnational Exchange in Sri Lanka and Ghana," in New Approaches to Migration: Transnational Communities and the Transformation of Home, ed. N. Al-Ali and K. Koser (New York: Routledge, 2002), 202-223. For a discussion of political activities see: Basch et al.

18. A. Mountz and R.A. Wright, "Daily Life in the Transnational Migrant Community of San Agustin, Oaxaca, and Poughkeepsie, New York," Diaspora 5 (1996): 403-427.

19. K. Sherrell, J. Hyndman, and F. Preniqi, "Sharing the Wealth, Spreading the 'Burden'? The Settlement of Kosovar Refugees in Smaller BC Cities" (Working Paper No. 04-06, RIIM, Vancouver, 2004).

20. Portes et al.; and A. Portes, "Introduction: The Debates and Significance of Immigrant Transnationalism," Global Networks 1(2001): 181-93.

21. D. Hiebert and D. Ley, "Characteristics of Immigrant Transnationalism in Vancouver” (Working Paper 03-15, RIIM, Vancouver, 2003).
22. Portes, "Immigration Theory for a New Century," 812

23. Hiebert and Ley.

24. A.M. Barrenechea, "Under Many Fires: The Lives of Women Refugees," Canadian Woman Studies / les cahiers de la femme, 15 (1995): 1-33; L. Ryan and J. Woodill, "A Search for Home: Refugee Voices in the Romero House Community (CERIS, Toronto, 2000); and H.S. Mohamed, "Resistance Strategies: Somali Women's Struggles to Reconstruct Their Lives in Canada," Canadian Woman Studies / les cahiers de la femme 19(1999): 52-57.

25. Without a Canadian passport, Kosovars are prohibited from travelling to Serbia and Montenegro. Consequently, those Kosovars who have visited Kosovo/a spoke of having travelled through Germany and Austria.

26. Al-Ali et al., "The limits to 'transnationalism"”; Al-Ali et al., "Refugees and transnationalism."

27. Of the 850,000 ethnic Albanian Kosovars believed to have left the province for surrounding countries, approximately 250,000 fled to the Former Yugoslav Republic of Macedonia. The refugees threatened to upset the balance among ethnic groups in Macedonia, prompting a large-scale, United $\mathrm{Na}$ tions (UN) sponsored humanitarian evacuation of Kosovar refugees from camps in Macedonia to states further afield. For more in-depth discussion see: T. Judah, Kosovo: War and Revenge (London: Yale University Press, 2000); and M. J. Calic, "Kosovo in the Twentieth Century: A Historical Account," in Kosovo and the Challenge of Humanitarian Intervention: Selective Indignation, Collective Action, and International Citizenship, ed. A. Schnabel and R. Thakur (New York: United Nations University Press, 2000), 19-31.

28. B. Abu-Laban, T. Derwing, M. Mulder, and H.C. Northcott, Lessons Learned: An Evaluation of Northern Alberta's Experience with Kosovar Refugees (Prairie Centre of Excellence for Research on Immigration and Integration and Population Research Laboratory, University of Alberta, Edmonton, 2001).

29. Portes, "Immigration Theory for a New Century," 812.

30. All Kosovars were given the option of having a sponsor, and provisions were made for up to two years of income support, as well as coverage under the Interim Federal Health Plan (Abu-Laban et al.). In addition to the chance for immediate repatriation or permanent settlement in Canada, Kosovars were given a two-year time frame during which the Federal Government would assume full costs if they chose to repatriate. See E. Tetrault and L. Tessier, "Notes for a statement by the Minister of Citizenship and Immigration The Honourable Lucienne Robillard on the Return of Kosovar Refugees," CIC Canada News Release 1999-28, Montreal, July 2, 1999; and United States Committee for Refugees and Immigrants (USCR), "Canada," in World Refugee Survey 2000: An Annual Assessment of Conditions Affecting Refugees, Asylum Seekers, and Internally Displaced Persons, Immigration and Refugee Services of America: 295 (2000).

31. Al-Ali et al., "Refugees and Transnationalism," 628.

32. Al-Ali et al., "Refugees and transnationalism," 628. 
33. UN (United Nations) Security Council, "Resolution 1244 (1999)". Adopted by the Security Council at its $4011^{\text {th }}$ meeting on 10 June 1999a, <http://ods-dds-ny.un.org/doc/UNDOC/ GEN/N99/172/89/PDF/N9917289.pdf?OpenElement (accessed February 21, 2004).

34. UN Security Council, "Resolution 1272 (1999)". Adopted by the Security Council at its $4057^{\text {th }}$ meeting on 25 October 1999b, <http://ods-ddsny.un.org/doc/UNDOC/GEN/N99/ 312/77/PDF/N9931277.pdf?OpenElement> (accessed February 21, 2004); and F. Hochschild, "'It Is Better to Leave, We Can't Protect You': Flight in the First Months of United Nations Transitional Administrations in Kosovo and East Timor," Journal of Refugee Studies 17 (2004).

35. This is the first of numerous quotations from interview and focus group transcripts with both individual Kosovar immigrants and service providers at immigrant and refugee-serving agencies. They are included to illustrate, in their own words, the issues as immigrant service providers and the Kosovars themselves understand them. We have not cited them in the usual fashion, as all the quotations in this article are taken from the same sources. Complete source information is available from the authors.

36. M. Glenny, "Asleep at the Wheel in Kosovo: The EU Is Wasting the Chance to Bring Lasting Peace to the Balkans," The Guardian, September 9, 2003, <http://www.guardian.co.uk> (accessed September 10, 2003).

37. Reuters, "Serbia, Kosovo Talks Now Weeks Away-U.N. Governor," Reuters AlertNet, September 9, 2003, <http:// www.alertnet.org $>$ (accessed September 10, 2003).

38. Glenny.

39. Helsingin Sanomat, "Appointment of Harri Holkeri as Kosovo Administrator Confirmed," Helsingin Sanomat: International Edition, July 29, 2003, <http://www.helsinki-hs.net/ news $>$ (accessed September 3, 2003).

40. M. Price, "Kosovo's Deep Divide," BBC News World Edition, October 13, 2003, <http://news.bbc.co.uk/2/hi/europe/ 3186800.stm > (accessed February 24, 2004).

41. For the Kosovars in BC, significant variations exist between centres in relation to both unemployment and attachment to the labour force. Some Kosovars, particularly in the Lower Mainland, spoke of fairly constant attachment to the labour force, albeit in a variety of jobs, while the majority of participants in Kelowna and Vernon spoke of having worked for as little as one or two months since coming to Canada. (Sherrell et al. 2004).

42. Al-Ali et al., "Refugees and Transnationalism."

43. Hiebert and Ley.

44. Al-Ali et al., "The Limits to 'Transnationalism," 591.

45. The ability to integrate and maintain identity and culture is guaranteed under Canada's Multiculturalism Policy, which does not require newcomers to assimilate and forego previous identities.

46. Longitudinal research on transnational relations could illuminate the extent to which transnational relations may be a short- or medium-term strategy for settlement, but such analysis is beyond the scope of this study.

47. Al-Ali et al., "Refugees and Transnationalism." It is important to note that all adult Eritreans in the diaspora are obliged to remit 2 per cent of their annual incomes to the Eritrean state (K. Koser, "From Refugees to Transnational Communities?" in New Approaches to Migration: Transnational Communities and the Transformation of Home, ed. N. Al-Ali. and K. Koser (New York: Routledge, 2002), 139-52). Although Kosovars in the diaspora have not been subjected to the institutionalized "transnationalism from above," Prime Minister Bajram Rexhepi has begun to encourage members of the diaspora to utilize their business experience that has been obtained outside of Kosovo/a with their "special knowledge" of Kosovo/a to help rebuild Kosovo/a's economy [T. Reimers and S. Howell, "US Diaspora Keen to Invest," Focus Kosovo-Economy, October 2002, <http://www.unmikonline.org/pub/focuskos/oct02/ focuskeco3.htm $>$ (accessed January 14, 2003)]. Despite the prevalence of informal remittances, the government is encouraging economic ties that will help begin the process of rebuilding [thus moving from "transnationalism from below" (driven by migrants) to "transnationalism from above" (driven by government)].

48. Al-Ali et al., "Refugees and Transnationalism," 628.

49. Although the sporadic gifts of money or clothes do not meet Portes's definition of transnationalism (see Portes, "Conclusion: Towards a New World"), we contend they expose transnational social fields that continuously link Kosovars in Canada with those "at home."

50. Anecdotal evidence indicates that many of the Kosovars who returned to Kosovo/a within the two-year window for repatriation are unhappy with their decision. For those who have remained in Canada, Canadian citizenship offers new opportunities. Deciding whether to remain in Canada or return to Kosovo/a with a Canadian passport in hand is analogous to the economic process of locational rationalization forwarded by Taylor and Thrift. See M. J. Taylor and N. Thrift, eds., Multinationals and the Restructuring of the World Economy (London: Croom Helm, 1986); and Sherrell et al.

51. N. Glick Schiller, L. Basch, and C. Blanc-Szanton, "Transnationalism: A New Analytic Framework for Understanding Migration," Annals of the New York Academy of Sciences 645 (1992): 1-24.

52. The proposed addition of questions relating to the reasons for taking up Canadian citizenship (or not) on Wave 3 of the Longitudinal Survey of Immigrants to Canada (LSIC) speaks to Government recognition of more strategic approaches to Canadian citizenship, something which has definite long-term implications for policy (E. Ruddick, "Longitudinal Survey of Immigrants to Canada: Report on Activities" (presentation given at RIIM/MCAWS Immigration Research Workshop, SFU Harbour Centre, Vancouver, February 24, 2004).

53. J.L. Waters, "The Flexible Family: Recent Immigration and 'Astronaut' Households in Vancouver, British Columbia" (Working Paper 01-02., RIIM, Vancouver, 2001). 
54. The International Organization for Migration (IOM) organizes elections, and Kosovars are eligible to vote if they obtain cards from Austria.

55. In contrast, almost all of the Kosovars interviewed indicated their intention to vote in Canada once they are eligible.

56. Judah, 251.

57. "Constitutive outside" recognizes identities as being relational and describes the demarcation of an identity through the establishment of a hierarchy, i.e. self-other, us-them. In recognizing difference, an "us" as from a "them," Mouffe points to the potential for an antagonistic, and political, relationship between the identities. For a more detailed discussion see C. Mouffe, 1994, "For a Politics of Nomadic Identity," in Travellers' Tales: Narratives of Home and Displacement, ed. G. Robertson et al. (New York: Routledge 1994), 105-113.

Kathy Sherrell is a Doctoral Student in the Department of Geography at the University of British Columbia. Her most recent research examined the settlement experiences and tran- snational relations among kosovar refugees in British Columbia.

Jennifer Hyndman, Ph.d., is an Associate Professor in the Department of Geography at Simon Fraser University. Her current research delves into the dynamics of immigration, including refugee resettlement in Canada and the transnational linkages that refugees maintain with other parts of the world.

Funding for this research was provided by the Vancouver Centre of Excellence for Research on Immigration and Integration in the Metropolis (RIIM), as well as from the Social Sciences and Humanities Research Council (SSHRC) Strategic Grant on Social Cohesion in Canada (Social cohesion and international migration in globalizing era: transnational solidarities and newcomer incorporation in Canada). 